\title{
NOTES ON THE GENUS SABIA (SABIACEAE) FROM VIETNAM
}

\author{
CHI-MING HU \& GANG HAO \\ South China Botanical Garden, the Chinese Academy of Sciences, \\ Guangzhou 510650, China
}

\section{SUMMARY}

Sabia uropetala Gagnep. \& Vidal is reduced to Sabia swinhoei Hemsl. as a synonym, and the identity of Embelia bonii Gagnep., cited in Flora of Vietnam, is clarified.

Key words: Sabiaceae, Sabia, Vietnam.

\section{INTRODUCTION}

In the course of revising the genus Embelia of Indochina, the authors came across a specimen named by F. Gagnepain as Embelia bonii (Bon 2284) on the herbarium sheet. Although the name was not effectively published, it was accepted by Hô (1991) and Lien (2002) respectively in their Illustrated Flora of Vietnam and Flora of Vietnam. However, the name has not been validated. The plant is a climber, with 5-merous flowers and the stamens as many as and opposite to the corolla-lobes; it is really similar in some respects to Embelia of the Myrsinaceae. However, the 2-locular ovary surrounded by a hypogynous disk indicated evidently that it belongs to Sabiaceae, and a further close study reveals that the plant matches Sabia uropetala Gagnep. very well in every respect.

Sabia uropetala is known only from the type specimen collected from northern Vietnam on the border area near Guangxi Province of China. In describing this new species, Gagnepain (1952) compared it with Sabia tomentosa Hook.f., a species restricted to Myanmar and quite different morphologically and geographically; later it was reduced to Sabia lanceolata Colebr. as a synonym by Van de Water (1980). At the same time Van de Water also noticed that Sabia uropetala is closely related to Sabia swinhoei from the neighbouring country China, but he maintained the species and listed a few trifle differences, e.g. the density of hairs and the length of sepals (1.25-1.75 vs $0.7-1.4)$. But the distinctions are too slight for recognition of it as a separate species. When more material was examined, the range of indumentum density and the length of sepals, petals and styles found made it impracticable to maintain it as a separate species. Therefore, the following reduction was found to be necessary. 
Sabia swinhoei Hemsl. - Fig. 1; Map 1

Sabia swinhoei Hemsl. (1886) 144; L. Chen (1943) 44; Water (1980) 58; Y.F. Wu (1985) 89. - Type: Swinhoe s.n. (holo K), China, Prov. Taiwan.

Sabia uropetala Gagnep. (1952) 271; Gagnep. \& Vidal (1960) 13; Water (1980) 58. - Type: Pételot 6675 (holo P), Vietnam, Prov. Bac Giang.

Embelia bonii Gagnep. in sched; P.H. Hô (1991) 860; T.T.K. Lien (2002) 205, f. 124, nom. inval.

Branchlets slender, laxly to densely pubescent. Petioles 3-10(-12) mm long, pubescent. Leaves elliptic, ovate-elliptic, oblong-elliptic or narrowly elliptic, sometimes obovate-elliptic, (2-)5-12 by (1-)2-6 cm, base cuneate to rounded, apex acuminate or abruptly and shortly acuminate to acute, adaxial surface glabrous, but \pm pubescent on midvein when young, abaxial surface over all laxly or densely pubescent, glabrescent in age; lateral nerves 4-6(-7) on each side of midvein, straight or curved, anastomosing at a distance of 5-8 $\mathrm{mm}$ from the margin. Cymes axillary, 2-6-flowered, solitary or sometimes arranged in an axillary thyrsoid inflorescence of $1-3 \mathrm{~cm}$ long, due to the subtending leaves reduced to bract-like (Fig. 1). Sepals ovate to oblong-triangular, 0.7-1.75 by $0.3-1 \mathrm{~mm}$, glabrous to pubescent. Petals lanceolate to ovate-lanceolate, (3.5-) 4-6 by $0.75-1.4 \mathrm{~mm}$. Stamens $1-1.6 \mathrm{~mm}$ long; filaments \pm flattened. Disk crown-shaped; lobes distinct. Ovary globular to subreniform; style $0.3-0.75(-1) \mathrm{mm}$ long. Drupelets \pm obovoid and compressed, $7-10$ by $6-8 \mathrm{~mm}$, blue or dark blue in fresh state.

Distribution - China mainland (Fujian, Zhejiang, Jiangsu, Jiangxi, Hubei, Sichuan, Guizhou, Hunan, Guangdong, Guangxi), Taiwan, and northern Vietnam.

a

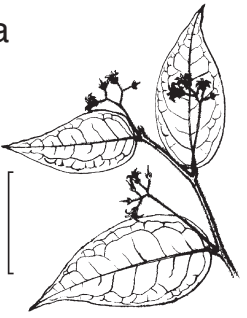

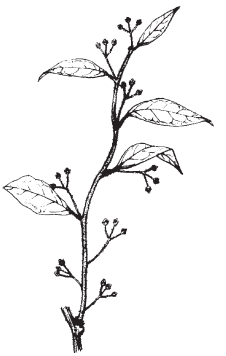

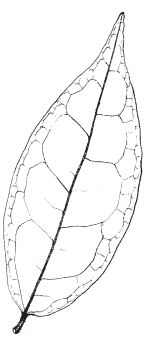

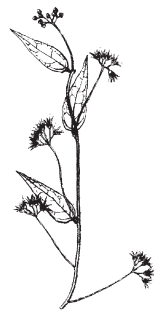
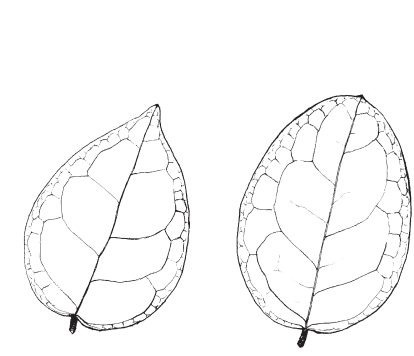
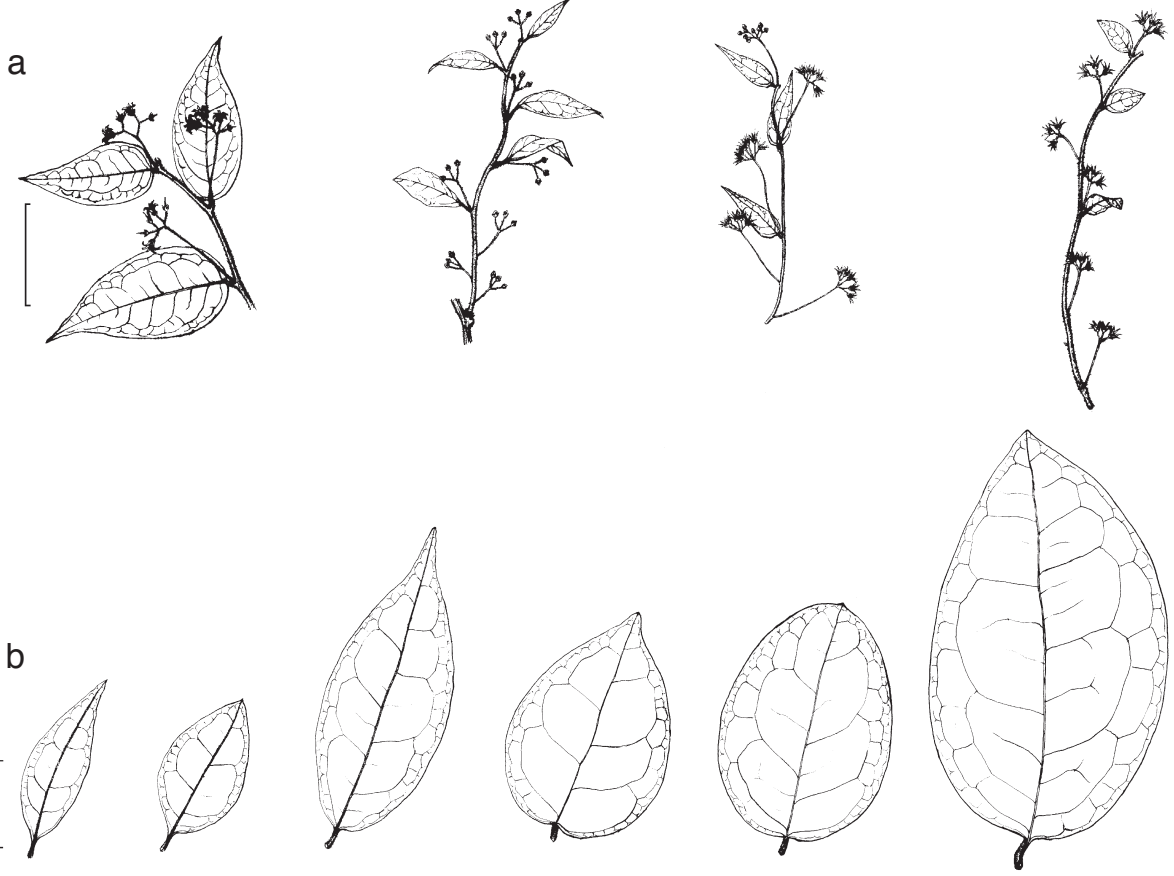

Fig. 1. Sabia swinhoei Hemsl. a. Variation of inflorescence; b. variation of leaf shape. Scale bar $=$ $1 \mathrm{~cm}$. 


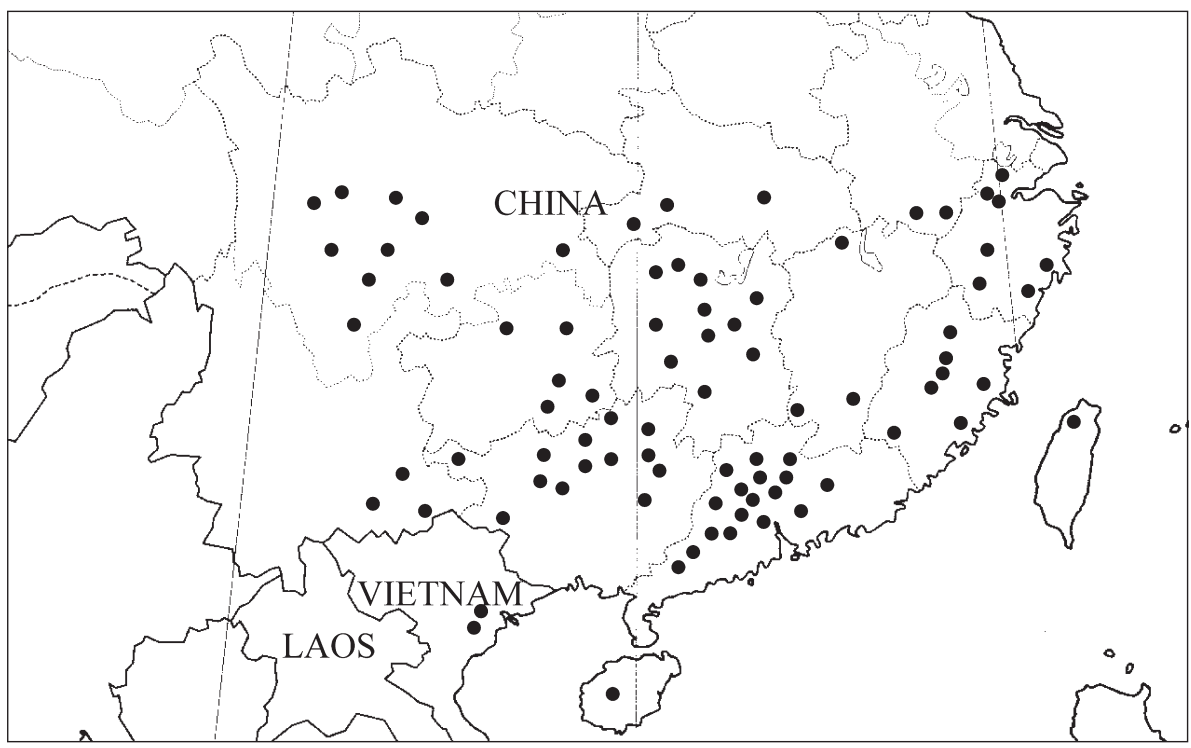

Map 1. Distribution of Sabia swinhoei Hemsl.

Habitat \& Ecology - Often on shady places in thickets and woods, at altitudes up to $1200 \mathrm{~m}$. Flowering: April to June; fruiting: July to October.

Note - A very variable species, showing variability in many characters (density of indumentum, size and shape of leaves, length of sepals, petals and style).

\section{ACKNOWLEDGEMENTS}

This study was supported by the National Natural Science Foundation of China (no. 30470125) and the Natural Science Foundation of Guangdong Province (no. 31255). We like to thank Yun-Xiao Liu for the drawing and Qing Liu for scanning and editing.

\section{REFERENCES}

Chen, L. 1943. A revision of the genus Sabia Colebr. Sargentia 3: 37.

Gagnepain, F. 1952. Sabiacées nouvelles d'Indochine: Sabia et Meliosma. Notul. Syst. (Paris) 14: 271-276.

Gagnepain, F. \& J. Vidal, 1960. Sabia. In: A. Aubréville, Flore du Cambodge, du Laos, et du Viêtnam 1: 12-18. Muséum National d'Histoire Naturelle, Paris.

Hemsley, W.B. 1886. Sabia. In: F. Forbes \& W. B. Hemsley, An enumeration of all the plants known from China proper, Formosa, Corea, the Luchu Archipelago, and the Island of Hong Kong. J. Linn. Soc. Bot. 23: 1-162.

Hô, P.H. 1991. Sabia. In: P.H. Hô, Illustrated Flora of Vietnam 1: 860. Tre Publishing House, Vietnam.

Lien, T.T.K. 2002. Sabia. In: T.T.K. Lien, Flora of Vietnam 4: 205. Science \& Technics Publishing House.

Van de Water, Th.P.M. 1980. A revision of Sabia (Sabiaceae). Blumea 26: 1-64.

Wu, Y.F. 1985. Sabia. In: Y.W. Law, Flora Reipublicae Popularis Sinicae 47: 73-96. Science Press,

Beijing. 